\title{
Motinų, auginančių raidos sutrikimų turinčius vaikus, motinystès streso ypatumai
}

\author{
Monika MATONYTÉa, ${ }^{\mathrm{a}, 1}$ Evelina VIDUOLIENÉ ${ }^{\mathrm{b}}$, Aidas PERMINAS $^{\mathrm{a}}$ \\ ${ }^{a}$ Vytauto Didžiojo universitetas \\ ${ }^{\mathrm{b}}$ Mykolo Romerio universitetas
}

\begin{abstract}
Santrauka. Tyrimai rodo, kad motinos, auginančios vaikus, kuriems dèl sveikatos būklès reikalinga speciali priežiūra, jaučia daugiau motinystės streso, palyginti su didesnių sveikatos problemų neturinčių vaikų šeimomis. Su vaiko priežiūra susijusios motinų psichologinès ịtampos tyrimai Lietuvoje yra gana neseniai išsamiau pradèta nagrinèti sritis. Prasminga analizuoti ne tik konkrečių sveikatos problemų turinčių šeimų prisitaikymą ir dèl vaiko priežiūros kylančius sunkumus, bet ir lyginti skirtingų sveikatos problemų turinčių vaikų šeimų atvejus. Tai leistų geriau suprasti tam tikra liga sergantị vaiką auginančiai motinai kylančius iššūkius, tiksliau numatyti psichologines jos reakcijas ir vaiko prisitaikymo, šeimos gerovès riziką. Tyrimo tikslas - nustatyti raidos sutrikimą turinčius arba lètine alergine liga sergančius vaikus auginančių motinu motinystès streso ypatumus, streso sasajas su šeimos socialiniais ir demografiniais veiksniais. Metodai. Darbe naudotas Motinystès streso klausimynas (Parenting Stress Index, Abidin, 1990), analizuoti motinystès streso ypatumai, priklausantys nuo vaiko elgesio ir motinos savijautos, šeimos sociodemografiniai veiksniai. Rezultatai. Motinų, auginančiu raidos sutrikimų turinčius vaikus, patiriamas motinystės stresas yra didesnis nei motinų, kurios augina sveikus ar sergančius lètinėmis alerginėmis ligomis vaikus. Stipresnis raidos sutrikimų turinčius vaikus auginančių motinų motinystės stresas yra siejamas su mažesniu motinos išsimokslinimu ir vyresniu vaiko amžiumi.
\end{abstract}

Pagrindiniai žodžiai: motinystės stresas, vaikai, turintys raidos sutrikimų, vaikai, sergantys lėtinėmis alerginèmis ligomis.

\section{Ivadas}

Tèvystès, motinystès stresas - tai psichologinè įtampa, atsirandanti dèl vaiko nepageidaujamo elgesio ir tèvų vaidmens keliamų reikalavimų, kai šie neatitinka tẻvų turimų išteklių jiems ígyvendinti (Abidin, 1990, 1995; Deater-Deckard, 2004). Vaiką supanti artimiausia aplinka, šeimos nariai, ypač motina, turi ịtakos jo raidai, sėkmingam prisitaikymui, gerovei. Ypač ši ịtaka svarbi ankstyvaisiais vaiko gyvenimo tarpsniais. Intensyvus tėvystès, motinystès stresas yra svarbus rizikos veiksnys ne tik vaiko psichosocialinei raidai, bet ir motinos bei šeimos gerovei. Nuolatinis aukštas motinystès streso lygis nepalankiai veikia motinų fizinę sveikatą ir miego kokybę, pasitenkinimą gyvenimu ir santuoka, didina motinų nuotaikos sutrikimų riziką (Abidin \& Wilfong, 1985; Lavee, Sharlin, \& Katz, 1996; Secco et al., 2006). 32 proc. motinų, auginančių raidos sutrikimų turinčius vaikus, buvo padidejusi rizika susirgti depresija; literatūros duomenys taip pat rodo, kad tėvams, auginantiems neigalius vaikus, dažniau pasireiškia depresijos požymiai nei tėvams, kurių vaikams nėra nustatyta negalia (Olsson \& Hwang, 2001; George \& Singer, 2006; Uskun \& Gundogar, 2010). Minèti veiksniai turi neigiamą ịtaką motinos ir vaiko tarpusavio santykiams, vaiko auklejjimui, taigi netiesiogiai veikia ir vaiko raidą.

Raidos sutrikimų turinčius vaikus auginančių motinų motinystès stresas siejamas su neišsipildžiusiais lūkesčiais dèl vaiko, prastesne jo adaptacija (Plant \& Sanders, 2007; Hedov, Annerén, \& Wikblad, 2002; Trute \& Hiebert-Murphy, 2002). Esant tam tikriems raidos sutrikimams, kaip antai autizmui ar mišriam emocijų ir elgesio sutrikimui, motinystės stresas gali padidèti ir dèl negaunamų teigiamų paskatinimų iš vaiko, jo negebejjimo išreikšti dèkinguma (Rentinck, Ketelaar, Jongmans, \& Gorter, 2007; Cox, Hopkins, \& Hans, 2000; Pukinskaitė ir Praninskienè, 2008). Vaiko poreikius tenkinančios motinos psichologinė reakcija gali priklausyti nuo vaiko sveikatos sutrikimo pobūdžio (Buton, Pianta, \& Murvin, 2001). Vaiko, turinčio įvairiapusi raidos sutrikimą, auginimas yra didelis krūvis šeimai, todèl šioms šeimoms reikalinga nuolatinè ir kompleksine psichologine ir socialinè pagalba. Esant lengvesniems vaiko sveikatos sutrikimams, pavyzdžiui, jam sergant lètinèmis alerginėmis ligomis, motinystès stresas padidèja dèl specialaus režimo poreikio ir igūdžių palaikyti ši režimą trūkumo (Buton, Pianta, \& Murvin, 2001). Alergiško vaiko auginimas iš tẻvų pareikalauja papildomų finansinių ir laiko išteklių rūpinantis vaiko mityba, organizuojant jo laisvalaikį ir bendravimą su bendraamžiais, renkantis ugdymo ịstaigą. Paprastai tiriamas tam tikra liga sergantį vaiką auginančių mamų stresas, nelyginant skirtingomis ligomis sergančius vaikus auginančių mamų streso (Perminas ir Viduolienè, 2012). Vaikų, turinčių skirtingo pobūdžio sveikatos 
sutrikimų, motinų savijautos palyginimas leistų geriau suprasti specifines tam tikra liga sergantị vaiką auginančios mamos problemas (streso ypatumus), tiksliau numatyti psichologines jos reakcijas ir pagalbos galimybes.

Su motinystės stresu gali būti siejami ir šeimos sociodemografiniai veiksniai. Pavyzdžiui, Bristol su kolegomis (1988) atliktas tyrimas rodo, kad vyresnių vaikų priežiūra ir auginimas tėvams kelia daugiau psichologinès įtampos. Kiti tyrèjai teigia priešingai - kuo vaikas jaunesnis, tuo motinystės stresas yra didesnis (Mash \& Johnston, 1990; Kuczynski \& Kochanska, 1990) arba neaptinka reikšmingų sąsajų tarp motinystės streso lygio ir vaiko amžiaus (Baker, 1994; Beckman, 1991). Analizuojant klinikinių grupių vaikų motinų atvejus, pastebėta, kad su vaiko amžiumi kinta ir motinos patirtis - ji nebe pirmą kartą susiduria su vaiko ligomis, igyja žinių, patirties, kaip elgtis ir kontroliuoti vaiko sveikatos būseną, tai gali lemti mažesnị motinystès stresą didèjant vaiko amžiui (Shaffer, 2012). Motinystès streso lygis taip pat gali būti siejamas su motinos amžiumi, jos išsilavinimu, šeimynine patirtimi, auginamų vaikų skaičiumi - dèl skirtingos patirties minètos sąlygos gali arba palengvinti vaiko priežiūrą ir motinos reakcijas ị su priežiūra susijusius iššūkius, arba jas apsunkinti (Deater-Deckard, 2004).

Užsienio šalyse dauguma tyrimų vertina vaiko elgesio sunkumų įtaką tėvų stresui. Dažniausiai yra atliekami klinikinių grupių vaikų (raidos ar fizinès negalios vaikų) ir jų tėvų tyrimai(Goldberg et al., 1997; Anthony et al., 2005). Lietuvoje motinystès stresas pradètas tirti visai neseniai (Viduoliené, 2013; Perminas ir Viduoliené, 2012). Čia aprašomame tyrime buvo siekiama išsiaiškinti, ar sutrikusios raidos vaiko auginimas ir priežiūra sukelia didesnị motinystès stresą nei didesnių sveikatos problemų neturinčio vaiko ar vaiko, sergančio lètine alergine liga, kuriam daugeliu atvejų reikalinga speciali priežiūra (dieta ir aplinka be alergenų, medikamentinis gydymas).

Darbo tikslas - palyginti motinų, auginančių raidos sutrikimų turinčius vaikus, motinų, auginančių lètine alergine liga sergančius vaikus, ir motinų, auginančių didesnių sveikatos problemų neturinčius vaikus, motinystės stresą ir nustatyti jo sąsają su šeimos socialiniais ir demografiniais veiksniais.

\section{Metodika}

\subsection{Tyrimo dalyviai}

Tyrime dalyvavo 233 2-5 metų amžiaus vaikus auginančios motinos. Analizuoti 202 respondentų duomenys, nes kai kuriems vaikams buvo diagnozuotos kelios ligos, todèl jų duomenys ị analizę nebuvo ịtraukti. 107 (53,0 \%) tyrimo dalyvės augino didesnių sveikatos problemų neturinčius vaikus, iš jų $51(42,9 \%)$ berniuką ir $56(55,4 \%)$ mergaites. $67(33,1 \%)$ tyrime dalyvavusios moterys augino vaikus, sergančius lètinėmis alerginėmis ligomis (jautrius maisto ir aplinkos alergenams), iš jų $37(55,2,1 \%)$ berniukus ir $30(44,1 \%)$ mergaičių. $28(13,9 \%)$ tyrimo dalyvės augino vaikus, turinčius raidos sutrikimų (cerebrinis paralyžius, autizmas, mišrus raidos sutrikimas, emocijų ir elgesio sutrikimas, kalbos sutrikimas, miego sutrikimai, genetine liga), iš jų 20 (71,4 \%) berniukų ir 8 (28,6 \%) mergaites. Motinų amžius 33,7 $\pm 5,7$ metų. Visos tyrimo dalyvių grupés tarpusavyje statistiškai reikšmingai nesiskyrè analizuojant motinų ir vaikų amžiaus, vaikų lyties, motinų išsilavinimo ir šeiminès padėties ypatumus ( $\chi^{2}$ ir Anova dispersinès analizès rezultatai $\mathrm{p}>0,05)$.

\subsection{Tyrime naudoti instrumentai}

Tyrime naudotas Motinystès / tèvystès streso klausimynas - dažniausiai tokio pobūdžio tyrimuose naudojama ir populiariausia pasaulyje su motinystès / tėvystès vaidmeniu susijusio streso vertinimo metodika, padedanti ịvertinti veiksnius, turinčius įtakos motinos patiriamam stresui. R. Abidin sukurtas klausimynas (Parenting Stress Index, Abidin, 1990) yra grindžiamas trimis ankstesniais modeliais, vertinančiais tėvų elgesi lemiančius veiksnius: Patterson elgesio modeliu (Abidin, 1995), Belsky (1984) tėvystei turinčių ịtakos veiksnių proceso modeliu ir Abidin tėvų streso modeliu (Abidin, 1992). Kadangi tyrime dalyvavo motinos, toliau šis klausimynas bus pristatomas kaip Motinystès streso klausimynas. Klausimyno vertimą ị lietuvių kalbą pagal mokslinèms metodikoms keliamus reikalavimus atliko viena iš autorių E. Viduolienè, priemonès psichometrinès charakteristikos, tinkamumo naudoti atliekant diferencinę diagnostiką ir validumo rodikliai pristatyti moksliniame straipsnyje (Perminas ir Viduoliene, 2013).

Metodika vertina tris pagrindines stresorių sritis: motinystès stresą, susijusị su vaiko ir motinos charakteristikomis, ir stresogeninius ịvykius šeimos gyvenime. Tyrime analizuotos nuo vaiko elgesio aspektų ir motinos savijautos aspektų priklausančio motinystès streso skalès ir subskalès:

- Su vaiko elgesio aspektais susijusį motinystès stresa vertina šios 6 subskalès: vaiko išsiblaškymo ir hiperaktyvumo, prastos nuotaikos, nepriimtinumo, prisitaikymo sunkumų, reiklumo tèvams, teigiamo pastiprinimo iš vaiko pusès nebuvimo. Šio pobūdžio motinystès stresas kyla dèl vaiko elgesio ar savybių, kuriuos motina vertina kaip nepriimtinus, vaiką kaip pernelyg aktyvų, išsiblaškiusị, dažnai prastos ir nepastovios nuotaikos, sunkiai prisitaikantị prie naujų situacijų ir nepateisinantị jos lūkesčių. Dėl šių charakteristikų vaiko auklèjimas ir priežiūra tampa sudètingi.

- $\quad$ Su motinos savijauta susijusị motinystès stresq vertina 7 subskalès: motinos kompetencijos stokos auklejjant vaiką, nepakankamo vaiko prieraišumo, motinos vaidmens ribojimo, socialinès izoliacijos, santykių su 
sutuoktiniu, motinos sveikatos ir depresijos. Dėl motinos charakteristikų kylantis motinystès stresas rodo problemas, kylančias dèl pačios motinos saviveiksmingumo stokos ir neefektyvaus funkcionavimo vykdant motinystės pareigas, jos depresiją, nerimą ar menką savivertę, atsirandančius dèl motinos pareigų vykdymo.

Nuo vaiko elgesio aspektų priklausantis motinystès stresas rodo nepasitenkinimą vaiku, jo elgesiu, charakterio savybėmis ar gebejjimais, o su motinos charakteristikomis susijęs motinystès stresas atspindi nepasitenkinimą savimi kaip motina ir neigiamą požiūrị ị motinos pareigų vykdymą. Šio tyrimo klausimyno skalių ir subskalių Cronbacho $\alpha$ $=0,60-0,91$. Papildomai buvo pateikiami vaiko ir šeimos sociodemografines charakteristikas - šeiminę padètị, auginamų vaikų skaičių, motinos išsimokslinimą, vaiko lytị, vaiko amžių, motinos amžių - vertinantys klausimai.

\subsection{Tyrimo eiga}

Tyrimas atliktas dviejuose specializuotuose ir penkiuose Kauno miesto vaikų lopšeliuose-darželiuose, Kauno vaikų abilitacijos centre, Apuolès dienos centre. Buvo gautas Švietimo skyriaus sutikimas atlikti tyrimą. Tyrimo anketoje buvo pristatyti tyrimo tikslas, rezultatų viešinimo, tyrimo dalyvių asmeninès informacijos konfidencialumo klausimai. Tyrimo dalyvėms anketos buvo pateiktos tyrejjų, o užpildžiusios jos jas grąžindavo užklijuotame voke per darželyje dirbančius specialistus.

Duomenų analizė buvo atlikta naudojant statistinès analizès sistemą SPSS 22.0 versiją, naudoti Student $\mathrm{t}$ kriterijus, tiesinè regresinè analizè. Statistinio reikšmingumo lygmuo $\alpha=0,05$.

\section{Rezultatai}

Palyginus motinų, auginančių raidos sutrikimų turinčius vaikus, taip pat sergančius lètinėmis alerginėmis ligomis, ir sveikus vaikus su vaiko elgesio aspektais ir su motinos savijauta susijusio motinystès streso vidurkius (Studento $t$ kriterijus) nustatyta, kad raidos sutrikimą turintị vaiką auginančių tyrimo dalyvių su vaiko elgesiu susijusio bendro motinystès streso bei atskirų jo komponentų vidurkiai buvo statistiškai reikšmingai didesni nei vaikus, neturinčius didesnių sveikatos problemų, auginančiųų grupèje (lentelè). Raidos sutrikimą turintị vaiką auginančios motinos ji vertino kaip labiau išsiblaškiusị ir hiperaktyvų, patiriantị daugiau prisitaikymo sunkumų, esantị prastos nuotaikos, keliantị didelius reikalavimus tèvams, nepakankamai besidžiaugiantį bendravimu su tèvais, palyginti su sveikus vaikus auginančiomis respondentėmis. Su motinos savijauta susijusių motinystès streso bei jo komponentų (stresas dèl kompetencijos auklėjant vaiką stokos, santykių su sutuoktiniu, socialinio atsiribojimo) vidurkiai raidos sutrikimų turinčius vaikus auginančių tyrimo dalyvių grupejje buvo statistiškai reikšmingai didesni nei sveikus vaikus auginančių motinų grupèje.

$\mathrm{Su}$ vaiko elgesiu susijusio bendro motinystès streso ir atskirų jo komponentų (stresas dèl vaiko hiperaktyvumo, teigiamo paskatinimo bendraujant su vaiku nebuvimo, vaiko nepriimtinumo, prisitaikymo sunkumų, jo reiklumo tėvams) vidurkiai motinų, auginančių raidos sutrikimų turinčius vaikus, grupejje buvo statistiškai reikšmingai didesni, nei vaikus, sergančius lètinėmis alerginèmis ligomis auginančiųų grupėje. Su motinos savijauta susijusio motinystės streso ir jo komponentų (stresas dẻl kompetencijos auklëjant vaiką stokos, suvaržymų, atsirandančių rūpinantis vaiku, ir socialinès izoliacijos) vidurkiai vaikus, turinčius raidos sutrikimų, auginančių tyrimo dalyvių grupejje buvo statistiškai reikšmingai didesni nei lètinėmis alerginėmis ligomis sergančius vaikus auginančiųu grupèje (lentelė).

Papildomai buvo analizuojama, kokie sociodemografiniai veiksniai gali būti susiję su raidos sutrikimą turinčių vaikų motinų motinystès streso komponentais. Patikrinti du tiesinès regresinès analizès modeliai, kuriuose nepriklausomi kintamieji buvo šeimos sociodemografiniai veiksniai (̌̌eiminè padètis (vaikas auga pilnoje / nepilnoje šeimoje), auginamų vaikų skaičius, motinos išsimokslinimas, vaiko lytis, amžius, motinos amžius). Priklausomas kintamasis modelyje buvo su vaiko elgesio aspektais (pirmas modelis) ir su mamos savijauta (antras modelis) susijęs motinystès stresas.

Nustatyta, kad nè vienas minètų šeimos sociodemografinių veiksnių nėra statistiškai reikšmingai susijęs su nuo vaiko charakteristikų priklausančiu motinystès streso lygiu: $F(6,21)=0,958, p=0,477$.

Vaikus, turinčius raidos sutrikimų auginančiųų didesnị su motinos savijauta susijusị motinystès stresą prognozuoja mažesnis motinos išsimokslinimas $(\beta=-0,402, \mathrm{p}<0,05)$ ir vyresnis sergančio vaiko amžius (ryšio tarp kintamųų statistinè tendencija $\beta=0,370, p=0,051$; modelio statistika $F(6,20)=2,622, p=0,049)$. 
Lentelė. Vaikus, turinčius raidos sutrikimą, sergančius lètine alergine liga, ir vaikus, neturinčius didesnių sveikatos problemų, auginančių tyrimo dalyvių motinystès streso palyginimas

\begin{tabular}{|c|c|c|c|c|c|}
\hline & $\begin{array}{l}\text { 1. Raidos } \\
\text { sutrikimas }\end{array}$ & $\begin{array}{l}\text { 2. Sveiki } \\
(\mathrm{N}=107\end{array}$ & $\begin{array}{l}\text { 3. Lètinè } \\
\text { alerginè liga }\end{array}$ & \multicolumn{2}{|c|}{ p-reikšmė } \\
\hline Skalè / subskalè & $\mathrm{M} \pm \mathrm{SD}$ & $\mathrm{M} \pm \mathrm{SD}$ & $\mathrm{M} \pm \mathrm{SD}$ & $\begin{array}{c}\text { Skirtumas tarp } \mathbf{1} \text { ir } \mathbf{2} \\
\text { grupių }\end{array}$ & $\begin{array}{c}\text { Skirtumas tarp } \mathbf{1} \text { ir } \mathbf{3} \\
\text { grupių }\end{array}$ \\
\hline $\begin{array}{l}\text { Su vaiko charakteristikomis } \\
\text { susijęs motinystes stresas }\end{array}$ & $126,9 \pm 29,1$ & $97,5 \pm 18,4$ & $103 \pm 23,64$ & 0,001 & 0,001 \\
\hline \multicolumn{6}{|l|}{ Stresas dėl vaiko: } \\
\hline Hiperaktyvumo & $26,4 \pm 6,2$ & $21,7 \pm 4,4$ & $23,1 \pm 5,2$ & $\mathbf{0 , 0 0 1}$ & $\mathbf{0 , 0 1 1}$ \\
\hline Prastos nuotaikos & $13,1 \pm 3,4$ & $11,4 \pm 2,9$ & $11,8 \pm 3,2$ & $\mathbf{0 , 0 1 4}$ & 0,09 \\
\hline Priimtinumo stokos & $21,2 \pm 6,6$ & $12,2 \pm 3,7$ & $13,3 \pm 4,7$ & 0,001 & $\mathbf{0 , 0 0 1}$ \\
\hline Prisitaikymo stokos & $29,4 \pm 6,3$ & $24,9 \pm 5,8$ & $25,7 \pm 7,4$ & $\mathbf{0 , 0 0 1}$ & $\mathbf{0 , 0 2}$ \\
\hline Reiklumo tėvams & $25,2 \pm 7,6$ & $17,7 \pm 4,6$ & $19,4 \pm 5,5$ & 0,001 & $\mathbf{0 , 0 0 1}$ \\
\hline $\begin{array}{c}\text { Teigiamų paskatinimų } \\
\text { bendravime su vaiku nebuvimo }\end{array}$ & $12,3 \pm 4,2$ & $9,2 \pm 2,6$ & $9,7 \pm 3,5$ & $\mathbf{0 , 0 0 1}$ & $\mathbf{0 , 0 0 3}$ \\
\hline $\begin{array}{c}\text { Su motinos charakteristikomis } \\
\text { susijęs motinystes stresas }\end{array}$ & $127,6 \pm 37,9$ & $111,2 \pm 21,1$ & $111,6 \pm 21,9$ & 0,04 & 0,04 \\
\hline \multicolumn{6}{|l|}{ Stresas dèl mamos: } \\
\hline Kompetencijos stokos & $28,4 \pm 9,5$ & $23,1 \pm 5,1$ & $24,2 \pm 6,2$ & $\mathbf{0 , 0 0 7}$ & $\mathbf{0 , 0 3}$ \\
\hline $\begin{array}{c}\text { Nepakankamo vaiko } \\
\text { prieraišumo }\end{array}$ & $12,8 \pm 4,0$ & $11,4 \pm 2,8$ & $11,6 \pm 3,4$ & 0,08 & 0,12 \\
\hline Patiriamų suvaržymų & $19,1 \pm 5,4$ & $17,7 \pm 4,4$ & $16,9 \pm 4,3$ & 0,15 & 0,04 \\
\hline Santykių su sutuoktiniu & $17,3 \pm 7,1$ & $14,8 \pm 5,1$ & $15,1 \pm 4,4$ & $\mathbf{0 , 0 3}$ & 0,12 \\
\hline Depresijos & $20,6 \pm 7,0$ & $19,0 \pm 5,1$ & $19,2 \pm 5,0$ & 0,2 & 0,3 \\
\hline Atsiribojimo & $15,4 \pm 5,1$ & $12,7 \pm 3,9$ & $12,2 \pm 3,6$ & $\mathbf{0 , 0 0 3}$ & $\mathbf{0 , 0 0 1}$ \\
\hline Sveikatos būklès & $13,4 \pm 4,2$ & $12,5 \pm 3,3$ & $12,4 \pm 3,0$ & 0,2 & 0,2 \\
\hline
\end{tabular}

\section{Rezultatų aptarimas}

Atliktas tyrimas atskleidè, kad motinų, auginančių raidos sutrikimų turinčius vaikus, motinystės stresas yra didesnis nei motinų, kurios augina sveikus vaikus ar sergančius lètinèmis alerginèmis ligomis. Gauti rezultatai paantrina kitu autorių teiginiams, kad tokị sutrikimą turinčio vaiko auginimas yra ypač stresogeniškas (Zeanah \& Larrieu, 2000). Tyrimo imtis nebuvo didelè, todèl tyrimo rezultatus reikètų vertinti atsargiai ir pakartoti surinkus dar didesnę imtí.

Tyrimu buvo nustatyta, kad motinos, auginančios raidos sutrikimų turinčius vaikus, patiria daugiau motinystès streso dèl vaikų elgesio, kuris pasireiškia per dideliu aktyvumu, nenusėdejjimu vienoje vietoje, išblaškomumu, dèmesio nekoncentravimu. Vaikai, turintys raidos sutrikimų, pasižymi fizinėmis, emocinėmis, intelektinėmis ir emocinėmis charakteristikomis, kurios neatitinka tėvų turètų lūkesčių dèl vaiko, tačiau kartu tokie vaikai pateikia motinoms daugiau reikalavimų (Zeanah \& Larrieu, 2000). Tokius vaikus auginančių mamų stresas taip pat didejja dèl vaikų blogesnio gebèjimo prisitaikyti prie savo fizinès ar socialinès aplinkos pokyčių. Kitaip nei sergantys lètinèmis alerginèmis ligomis, vaikai, turintys raidos sutrikimų, nemoka ar negali išreikšti teigiamų emocijų, taigi neatsidèkoja ar kitaip nepastiprina motinos vaidmens, o tai galëjo lemti didesnį su motinų gaunamais teigiamais paskatinimais bendraujant su vaiku susijusį motinystès stresą.

Lètinèmis alerginėmis ligomis sergantys vaikai pateikia daugiau reikalavimų ir reikalauja ypatingos priežiūros, palyginti su sveikais vaikai. Nors lètinès alerginès ligos nèra sunkios ir reikalauja mažiau motinos pastangų, vis tiek tokius vaikus auginančioms mamoms nustatomi didesni motinystès streso įverčiai nei sveikus vaikus auginančiu mamų grupėje. Tokios sveikatos būklès vaiko priežiūra reikalauja papildomų išteklių.

Motinų, auginančių vaikus, turinčius raidos sutrikimų, su motinos savijauta susijęs motinystès stresas yra intensyvesnis nei motinų, kurios augina sveikus vaikus ar sergančius lètinėmis alerginėmis ligomis. Tai siejama su vaiko elgesio problemomis, sutrikimo specifika ir savarankiškumo lygiu (Innocenti, Huh, \& Boyce, 1992; DeaterDeckard, 2004; Kliever, 1997). Didesnis stresas susijęs su motinų nekompetencija gali rodyti, kad vaikų, turinčiu raidos sutrikimų, motinos jaučia, jog buvimas motina reikalauja daugiau jègų, nei jos tikèjosi, dèl vaiko elgesio ir nepakankamų gebejjimų jị kontroliuoti, dèl pasitikèjimo savo jëgomis stokos jos gali suabejoti savo, kaip motinos, kompetencija, jausti specifinių žinių trūkumą auklèdamos specialios priežiūros reikalaujantị vaiką. Kadangi vaikai, turintys raidos sutrikimų, turi kitokių poreikių nei sveiki vaikai ar sergantys lètinėmis alerginèmis ligomis, motinos dažniau jaučiasi kontroliuojamos ir priklausomos nuo savo vaikų poreikių ir reikalavimų. Tai galètų paaiškinti aptiktus suvaržymo ir socialinès izoliacijos skirtumus (Miller, Gordon, Daniel, \& Diller, 1992) - vaiko, turinčio ypatingų poreikių, auginimas šeimoje keičia socialinius santykius su aplinkiniais, laisvalaikio galimybes, tokios šeimos gali jausti socialinę stigmą iš aplinkinių.

Motinų, auginančių raidos sutrikimų turinčius vaikus, patiriamas motinystès stresas statistiškai patikimai yra susijęs tik su vienu sociodemografiniu rodikliu - turimu motinos išsimokslinimu. Tai patvirtina, kad aukštesnio išsimokslinimo moterys ịvairias situacijas vertina kaip keliančias mažiau streso, jaučiasi labiau gebančios ịveikti problemas, taiko efektyvesnius problemu sprendimo būdus (Kalil \& Danzinger, 2000). Sąsajų su kitais sociodemografiniais rodikliais - vaiko lyties, amžiaus, motinos amžiaus, šeiminės padeties, auginamų vaikų 
skaičiaus - šio tyrimo metu nebuvo aptikta. Vierhaus su kolegomis (2013) teigimu, yra atlikta per mažai tyrimų, kad būtų galima atsakyti i klausimą, koks yra motinystès streso ir vaiko lyties veiksnio ryšys. Gali būti, kad įtaką turi ne biologinis lyties veiksnys, bet tèvų lūkesčiai dèl berniukams ir mergaitèms būdingo elgesio. Esant rimtesnių sveikatos problemų, šie lūkesčiai gali kisti. Šiame tyrime motinystės streso sąsajų su vaiko lytimi taip pat neaptikta.

Bristol ir kitų (1988) atliktas tyrimas rodo, kad vyresnių vaikų priežiūra ir auginimas tèvams kelia daugiau psichologinès įtampos. Tai patvirtina ir kitų tyrèjo išvados - didejjant vaiko amžiui, motinystės stresas didèja (Mash \& Johnston, 1990; Kuczynski \& Kochanska, 1990). Yra tyrimų, neaptinkančių reikšmingų sąsajų tarp motinystės streso ir vaiko amžiaus (Baker, 1994; Beckman, 1991). Mūsų tyrime ryškèja statistiškai patikimo ryšio tendencija, kad vyresnis vaiko amžius yra susijęs su didesniu motinystès stresu. Gali būti, kad vyresnių vaikų priežiūra reikalauja didesnių išteklių iš tėvų, ypač jei vaikas turi sutrikimą ir jo sveikata su amžiumi prastèja, o tèvai patiria lètinį motinystès / tėvystès stresą ir vaiko priežiūros, taip pat aplinkinių palaikymu situacija nesikeičia (ar net blogèja).

Ištekejjusios ar partnerị turinčios motinos jaučia mažesnị motinystès stresą nei vienišos mamos (Copeland \& Harbaugh, 2005). Tẻvai, turintys galimybę rūpesčiais pasidalyti su kitais, dažniau mano gali įveikti kasdienius, su vaiko priežiūra susijusius sunkumus, jaučia bendrumo jausmą su kitais tèvai, o tai keičia jų požiūrị i kasdienius sunkumus ir padidina atsparumą tėvystės, motinystės stresui (Belsky, 1984; Sepa, Frodi, \& Ludvigsson, 2004). Mamos, turinčios pakankamai artimų kontaktų ir jaučiančios socialinę aplinkinių paramą, patiria mažiau motinystès streso, nesvarbu, ar augintų sveikus, ar fizinę, psichikos negalią turinčius vaikus (Beckman, 1991). Dauguma šio tyrimo dalyvių buvo ištekejjusios ir su vaikais besilankančios specializuotose įstaigose, taigi gali būti, kad gaunama socialinė aplinkinių parama padeda sumažinti patiriamą motinystės stresą. Kita vertus, panašu, kad raidos sutrikimą turinčio vaiko auginimas gali neigiamai paveikti santykius su sutuoktiniu, tačiau ateityje reikètu patvirtinti, ar šis ryšys gali būti tiesiogiai siejamas su vaiko negalia, ar jị lemia kiti tarpiniai veiksniai.

Apibendrinant - galima teigti, kad šis tyrimas padeda geriau suprasti motinystès streso, auginant sergantị vaiką, ypatumus. Psichologinę ịtampą auginant vaiką gali padidinti ịvairūs biologiniai, socialiniai ir psichologiniai tiek vaiko raidą, tiek motinos ir vaiko santykius, tiek šeimą kaip sistemą veikiantys veiksniai. Motinystės stresas siejasi su vaiko liga ir socialiniais demografiniais šeimos kintamaisiais, taigi gilesnis šių reiškinių supratimas bei analizė prisidètų prie efektyvesnès pagalbos suteikimo, atsižvelgiant ị šių veiksnių daromą įtaką savijautai.

\title{
Išvados
}

1. Raidos sutrikimą turinčius vaikus auginančios motinos patiria intensyvesnị motinystès stresą, kylantị dèl nepageidaujamo vaiko elgesio ir jo savybių, bei intensyvesnį motinystės stresą, susijusị su nepakankama motinos kompetencija auklejant vaiką, santykiais su sutuoktiniu, socialiniu atsiribojimu nuo aplinkinių, nei sveikus vaikus auginančios motinos.

2. Raidos sutrikimą turinčius vaikus auginančios motinos patiria intensyvesnị motinystès stresą, susijusį su vaiko hiperaktyvumu ir išsiblaškymu, prisitaikymo sunkumais, didesniu vaiko reiklumu, nepakankamu vaiko priimtinumu ir teigiamų paskatinimų iš vaiko pusès stoka, taip pat motinos vaidmens keliamais suvaržymais, nepakankama savo kompetencija auklejjant vaiką, dèl rūpinimosi vaiku kylančia socialine izoliacija, nei lètine alergine liga sergančius vaikus auginančios motinos.

3. Vaiką, kuriam diagnozuotas raidos sutrikimas, auginančios mažesni išsimokslinimą turinčios motinos patiria intensyvesnị su motinos savijauta siejamą motinystès stresą. Vyresnis raidos sutrikimą turinčio vaiko amžius taip pat siejamas su intensyvesniu motinystès stresu.

\section{Padèka}

Dèkojame įstaigoms ir mamoms, sutikusioms dalyvauti šiame tyrime.

\section{Maternal parenting stress of mothers raising children with developmental problems}

\author{
Monika MATONYTEE ${ }^{\mathrm{a}, 1}$, Evelina VIDUOLIENE' ${ }^{\mathrm{b}}$, Aidas PERMINAS \\ ${ }^{a}$ Vytauto Didžiojo universitetas \\ ${ }^{\mathrm{b}}$ Mykolo Romerio universitetas
}

${ }^{1}$ Corresponding author: matonyte.monika@gmail.com

Abstract. Foreign scientific studies show that mothers who raise children with developmental disabilities or chronic disease feel more parenting stress compared to mothers whose children do not have specific health problems. The aim of the 
study was to analyse and compare maternal parenting stress (stress related to child and to parent characteristics) between mother groups whose children have developmental disabilities, whose children have chronic allergy and need special care and healthy children, and to also evaluate the relationship between parenting stress and family sociodemographics. Methods. Parenting Stress Index (Abidin, 1990) was used and Child domain, Parent domain and 13 subscales were analysed. Results. Mothers who raise children with developmental disorder perceive higher Child domain parenting stress and parenting stress related to parenting competence, relationship with spouse and maternal role restrictions compared to mothers who have healthy children. Mothers who have children with developmental disorder perceive their child as more hyperactive and have more parenting stress related to child's acceptability, adaptability, demandingness and positive reinforcement absence, as well related to parenting incompetence, social isolation and role restriction compared to mothers who raise children with chronic allergy. Mothers who raise older children with developmental disorder or have lower education perceive higher Parent domain parenting stress.

Keywords. Maternal parenting stress, children with developmental disorder, children with chronic allergy. 


\section{Literatūra}

Abidin R. (1990, 1995). The parenting Stress index (3rd ed.) Psychological Assessment Resources: Odesa, FL.

Abidin R. (1992). The determinants of parenting behaviour. Journal of clinical Child Psychology, 21, 407-412.

Abidin R., Wilfong E. (1985). Parenting stress: Maternal and Child Health Correlates. Paper presented at annual convention of the APA.

Anthony L. G., Anthony B. J., Glanville D. N., Naiman D. Q., Waanders C., Shaffer S. (2005). The relationships between parenting stress, parenting behaviour and preschoolers' social competence and behaviour problems in the classroom. Infant and Child Development, 14 (2), 133154.

Baker D. B. (1994). Parenting stress and ADHD: A comparison of mothers and fathers. Journal of Emotional and Behavioral Disorders, 2 (1), 46-50.

Beckman J. (1991). Comparison of mothers' and fathers' perceptions of the effect of young children with and without disabilities. American Journal on Mental Retardation, 95, 585-595.

Belsky J. (1984). The determinants of parenting: A process model. Child Development, 55, 83-96.

Bristol M. M., Gallagher J. J., Schopler E. (1988). Mothers and fathers of young developmentally disabled and nondisabled boys: Adaptation and spousal support. Developmental Psychology, 24, 441-451.

Copeland D., Harbaugh B. (2005). Differences in parenting stress between married and single first time mothers at six to eight weeks after birth. Issues in Comprehensive Pediatric Nursing, 28, 139-152.

Cox S. M, Hopkins J., Hans S. L. (2000). Attachment in preterm infants and their mothers: neonatal risk status and maternal representations. Infant Mental Health Journal, 21, 464-80.

Deater-Deckard K. (2004). Parenting stress. New Haven, CT: Yale University Press.

George H. S. Singer (2006) Meta-Analysis of Comparative Studies of Depression in Mothers of Children With and Without Developmental Disabilities. American Journal on Mental Retardation, 111 (3), 155-169.

Goldberg S., Janus M., Washington J., Simmons R. J., MacLusky I., Fowler R. S. (1997). Prediction of Preschool Behavioral problems in healthy and pediatric samples. Journal of Developmental and Behavioral Pediatrics, 18 (5), 304-313.

Hedov, G., Annerén, G., Wikblad, K. (2002). Swedish parents of children with Down's syndrome. Scandinavian Journal of Caring Sciences, $16,424-430$.

Innocenti M. S., Huh K., Boyce G. C. (1992). Families of children with disabilities: Normative data and other considerations on parenting stress. Topics in Early Childhood Special Education, 12, 403-427.

Kalil A., Danzinger S. (2000). How teen mothers are faring under welfare reform. Journal of Social Issues, 56, $775-798$.

Kliewer, W (1997). Children's coping with chronic illness. In Wolchik and Sandler (Eds.) Handbook of Children's Coping: Linking Theory and Intervention. New York: Plenum Press.

Kuczynski L., Kochanska G. (1990). Development of children's noncompliance strategies from toddlerhood to age 5. Developmental Psychology, 26(3), 398-408

Lavee Y., Sharlin S., Katz R. (1996). The effect of parenting stress on marital quality. Journal of Family Issues, 17, $114-135$.

Mash E. J., Johnston C. (1990). Determinants of parenting stress: Illustrations from families of hyperactive children and families of physically abused children. Journal of Clinical Child Psychology, 19, 313-328.

Miller A. C., Gordon R. M., Daniel R. J., Diller L., (1992). Stress, appraisal and coping in mothers of disabled and nondisabled children. Journal of Pediatric Psychology, 17, 587-605.

Olsson, M. B., Hwang, C. P. (2001), Depression in mothers and fathers of children with intellectual disability. Journal of Intellectual Disability Research, 45, 535-543.

Perminas A. Viduolienė E. (2012). Maternal parenting stress and the health status of the child. Jaunuju mokslininku darbai, 2 (35), 66-7.

Perminas A., Viduoliene E. (2013). The Lithuanian version of the Parenting stress index (PSI): psychometric and validity investigation. European scientific journal, 9 (20), 66-80.

Plant, K. M., Sanders, M. R. (2007). Predictors of care-giver stress in families of preschool-aged children with developmental disabilities. Journal of Intellectual Disability Research, 51 (2), 109-124.

Pukinskaitė R., Praninskienė R. (2008) Motinų patirtis auginant sutrikusios raidos vaikus: vidinių reprezentacijos ypatybės. Medicina, 44 (7), 553-563.

Rentinck, I. C. M., Ketelaar, M., Jongmans, M. J., Gorter, J. W. (2007). Parents of children with cerebral palsy: a review of factors related to the process of adaptation. Child: care, health and development, 33(2), 161-169.

Secco M.L., Askin D., Yu D. Garinger J. at al. (2006). Factors affecting parenting stress among biologically vulnerable toddlers. Issues in Comprehensive Pediatric Nursing, 29 (3), 131-156.

Sepa, A., Frodi, A., Ludvigsson, J. (2004). Psychosocial correlates of parenting stress, lack of support and lack of confidence/security. Scandinavian journal of psychology, 45 (2), 169-179.

Shaffer, C. M. (2012). Parenting stress in mothers of preschool children recently diagnosed with autism spectrum disorder. Doctoral dissertation, Rutgers University-Graduate School-Newark). Retrieved from http://dx.doi.org/doi:10.7282/T3GX49HQ

Trute, B., and Hiebert-Murphy, D. (2002). Family adjustment to childhood developmental disability: A measure of parent appraisal of family impacts. Journal of Pediatric Psychology, 27 (3), 271-280.

Uskun, E., Gundogar, D. (2010). The levels of stress, depression and anxiety of parents of disabled children in Turkey. Disability and rehabilitation, 32 (23), 1917-1927.

Viduolienè E. (2013). Motinystès streso ir stresogeninių aplinkybių šeimos gyvenime reikšmė vaiko emocinių ir elgesio sunkumų kitimui vienerių metų laikotarpiu. Daktaro disertacija. Kaunas: VDU, 180 p.

Vierhaus, M., Lohaus, A., Schmitz, A. K., Schoppmeier, M. (2013). Relationships between Maternal Parenting Stress and Reports on Children's Internalizing and Externalizing Problems: A Cross-Lagged Structural Equation Model. Journal of Educational and Developmental Psychology, 3 (1), 39-50.

Zeanah, C. H., Larrieu, J. A. (2000). Mother-blaming, relationship psychopathology, and infant mental health: A commentary on Ward, Lee, and Lipper (2000). Infant Mental Health Journal, 21(6), 443-447. 